\title{
Clinical and Endoscopic Profile of Periampullary Tumour in a Tertiary Care Hospital
}

\author{
Rithesh Reddy G., Vijay Kumar T R., Nandeesh H P., Deepak Suvarna, Aradya H V., Anurag Lavekar, \\ Anil Kumar G.
}

Department of Medical Gastroenterology, JSS Medical College and Hospital, JSS Academy of Higher Education \& Research

\section{ABSTRACT}

Background and aims: Periampullary tumour is a clinical condition often encountered by gastroenterologist and surgeon. There is limited data regarding clinical profile and endoscopic management of patients with periampullary tumour.

Methods: We retrospectively analyzed the ERCP (Endoscopic retrograde cholangio pancreatography) records of periampullary tumour patients who were referred to Department of Gastroenterology for ERCP over a period of three years from January 2015 to January 2018. Demographic profile, clinical findings and ERCP management were taken into consideration. Statistics used were mean and standard deviation for continuous variables, frequencies and percentages were calculated for categorical Variables were determined.

Results: We retrospectively analyzed 86 patients who had undergone ERCP for Periampullary tumours from January 2015 to January 2018. Data interpretation revealed, that majority of the cases were between 41 to 50 years $(23.6 \%)$. There was a male preponderance (66.3\%). Maximum number of cases were of ampullary growth (46.5\%), followed by lower CBD stricture (32.6\%). The predominant presenting symptom was jaundice (77.9\%), followed by abdominal pain (54.6\%). 12 patients (14\%) had cholangitis at presentation. Mean bilirubin in the current study ranged from 11.76 to 23.72. CBD cannulation was achieved in $98.8 \%$ cases (Selective cannulation $65.1 \%$, precut sphincterotomy $33.7 \%$ ). Biliary drainage was done using plastic biliary stent (PC) in $84.7 \%$ and SEMS (self-expandable metallic stent) in $15.2 \%$ cases. Ampullary growth biopsy and biliary brush cytology revealed malignancy in 55\% and $35.7 \%$ cases respectively. At 3 months, 4 patients with PC stent developed block.

Conclusion: In our study, ampullary growth was the most common type of Periampullary tumour. Cholangitis was present in $14 \%$ cases at presentation. ERCP had good success for biliary drainage.Ampullary growth biopsy and biliary brush cytology has sensitivity rate of $50 \%$ and $35.7 \%$ respectively. Rate of PC stent block was low $(<5 \%)$.

Key words: periampullary tumour, carcinoma head of pancreas, ERCP, ampullary biopsy

\section{INTRODUCTION}

Periampullary cancers can be broadly considered as those tumours arising out of or within $2 \mathrm{cms}$ of the ampulla of Vater and include ampullary, pancreatic,
Corresponding author: Dr. Vijay Kumar T R, Asst Prof Department of Medical Gastroenterology, 8884367224 E-mail: drvijaytr@yahoo.com
Received: 25.08.2019 Accepted: 27.09.2019

Copyright () Celsius Publishing House www.sgo-iasgo.com 
distal bile duct, and duodenal cancer. These tumors are derived either from the epithelium, connective tissue, lymphoid tissue or the neuroendocrine cells in that anatomical region (1). Incidence of periampullary carcinoma is low approximately $0.5-2 \%$ of all gastrointestinal malignancies and $20 \%$ of all tumours of the extrahepatic biliary tree $(2,3,4)$. The greater majority of patients with periampullary tumour will not undergo surgical resection either due to advanced nature of the disease or the significant co-morbidity precluding surgery, therefore the mainstay of palliating jaundice is by stent placement at ERCP. We have performed a 3 year retrospective analysis of all the patients referred for ERCP to Gastroenterology department, at JSS hospital.

\section{METHODS}

\section{Study Design}

This is a cross sectional observational study of patients presenting with features of periampullary tumour at a tertiary care centre (JSS Hospital, Mysore, India) during January 2015 to January 2018. Computerized electronic record system was used to generate the data. Ethical clearance has been obtained prior to the initiation of the study. Inclusion criteria for the study was, patients who were admitted for periampullary tumor by clinical profile, laboratory investigations and imaging modalities were included in this study. Profiles of 86 patients, over 3 year period, with Periampullary tumour were analyzed. Post ERCP, patients were followed up at 1 and 3 months.

\section{Data Analysis and Interpretation}

Data was entered into Microsoft Excel (Windows 7; Version 2007) and analyses were done using the Statistical Package for Social Sciences (SPSS) for Windows software (version 22.0; SPSS Inc, Chicago). Descriptive statistics such as mean and standard deviation (SD) for continuous variables, frequencies and percentages were calculated for categorical Variables were determined. Association between Variables was analyzed by using Chi-Square test for categorical Variables. ANOVA was used to compare mean between groups having more than 2 categories. Bar charts and Pie charts were used for visual representation of the analyzed data. Level of significance was set at 0.05 .

\section{RESULTS}

During the study period, 86 patients who were
Table 1 - Distribution of study subjects according to their age group $(\mathrm{N}=86)$

\begin{tabular}{lcc}
\hline Age (in Years) & No. & Percent \\
\hline$\leq 40$ & 5 & 5.8 \\
$41-50$ & 22 & 25.6 \\
$51-60$ & 18 & 20.9 \\
$61-70$ & 19 & 22.1 \\
$71-80$ & 15 & 17.4 \\
$>80$ & 7 & 8.1 \\
\hdashline Mean (SD) & $60.80(13.20)$ \\
Range & \multicolumn{2}{c}{$36-86$} \\
\hline
\end{tabular}

satisfying inclusion criteria were included in the study and their data was recorded. Data analysis revealed that majority of the periampullary tumour cases were between the age group 41 to 50 years (22 cases) (accounting for $25.6 \%$ ), next highest number of cases were found between the age group 61 to 70 years (19 cases) (accounting for 22.1\%) (table 1).

There was a male preponderance in the current study, 57 cases $(66.3 \%)$, while female cases were 29(33.7\%). Among periampullary tumour cases, the maximum number of cases found were of ampullary growth 40 cases( $46.5 \%$ ), followed by lower CBD stricture 28 cases (32.6\%), 16 cases of carcinoma head of the pancreas (18.6\%) and 2 cases of duodenal malignancy $(2.3 \%)$ were found (table 2 ).

The predominant presenting complaint was jaundice (77.9\%), followed by abdominal pain (54.6\%), pruritis ( $24.4 \%$ ) and vomiting (1.16\%). 12 patients among $86(14 \%)$ had cholangitis at presentation. An association between profile and serum bilirubin was studied among the above set of patients in the study, D2 growth patients had a mean distribution of 23.72 serum bilirubin, lower CBD stricture patients had mean distribution of 17.09 serum bilirubin, followed by carcinoma head of the pancreas patients who had mean distribution of 14.2 serum bilirubin and Ampullary growth patients had mean distribution of 11.76 serum bilirubin (table 3 ).

CBD cannulation was achieved in $98.8 \%$ cases (Among which precut sphincterotomy was done for $33.7 \%)$, one patient could not be cannulated (1.2\%).

Table 2 - Distribution of study subjects according to the profile $(\mathrm{N}=86)$

\begin{tabular}{lcc}
\hline Profile & No. & Percent \\
\hline Ampullary Growth & 40 & 46.5 \\
\hdashline Lower CBD Stricture & 28 & 32.6 \\
\hline Ca Head of Pancreas & 16 & 18.6 \\
\hline Duodenal malignancy & 2 & 2.3 \\
\hline
\end{tabular}


Table 3 - Association between profile and serum bilirubin $(\mathrm{N}=86)$

\begin{tabular}{lcc}
\hline Profile & Mean Bilirubin & SD \\
\hline Ampullary Growth & 11.76 & 8.66 \\
\hline Ca Head of Pancreas & 14.20 & 8.28 \\
\hdashline Lower CBD Stricture & 17.09 & 9.77 \\
\hline Duodenal malignancy & 23.72 & 14.38 \\
\hline
\end{tabular}

ANOVA, $P$ Value $=0.050$, Significant

Among 29 patients who had precut sphincterotomy, 9 patients could not be cannulated initially; they were recannulated after 48 hours. Among the one patient who couldnot be cannulated, had Carcinoma head of pancreas, he had underwent PTBD (Percutaneous Transhepatic Biliary Drainage) eventually. Among 85 patients who underwent ERCP, plastic stent was used in 72 patients (84.7\%), SEMS (self-expandable metallic stent) was used in 13 patients(15.2\%) for biliary drain. Among 40 patients who had ampullary growth on presentation, ampullary biopsy report revealed chronic nonspecific inflammatory lesion among 18 patients (45\%), moderately differentiated adenocarcinoma in 16 patients (40\%) poorly differentiated adenocarcinoma in 4 patients (10\%), well differentiated adenocarcinoma in 2 patients (5\%). 28 patients who had lower CBD stricture on presentation, biliary brush cytology report revealed benign ductal epithelial cells in 18 patients (64.2\%), malignant cells in 10 patients (35.7\%). 4 patients were readmitted for stent block and stent exchange within 3 months. Among the four patients who had stent exchange, 2 patients had carcinoma head of the pancreas and two patients had Ampullary growth.

\section{DISCUSSION}

Periampullary tumours are found predominantly in the older age groups. According to the age-specific rates, the incidence of cancers of the ampulla began to increase after age 30 , but increased more rapidly after age 50 in both men and women; average age at diagnosis is between 60 and 70 years. Among 86 patients of periampullary tumour in our study, common age group of presentation was between 41 to 50 years $(25.6 \%)$, followed by 61 to 70 years (22.1\%). The results of our study were comparable to the study done by Sultan HM et al, where the mean age of the studied group was 56 years with a range of 32-73 years (5). Data from the surveillance, epidemiology, and end results registries according to Albores-Saavedra $\mathrm{J}$ et al have indicated that average age at diagnosis ranging from 60 to 70 years old (6-8). In present study there was slight male predominance at sex ratio 1:0.52 which correlates with similar studies by Lillemoe KD, Cameron JL, Pain JA 1:0.76 and Parks RW at 1: $0.98(4,6)$. In a study conducted by Albores-Saavedra J et al also concluded that women were found to be less frequently affected (0.36/100000) than men (0.56/100000, $P<0.05)(6)$. In our study the maximum number of cases found were of ampullary growth $(46.5 \%)$ followed by lower CBD stricture (32.6\%). The predominant presenting complaint was jaundice (77.9\%), followed by abdominal pain $(54.6 \%) .14 \%$ of patients had cholangitis at presentation. According to Bakkevold KE et al, obstructive jaundice is the most common presenting symptom of ampullary cancer $(85 \%)(9,10,11)$. Our study was in correlation with the study performed by Van Wagensveld BA et al reported jaundice as a presenting symptom in $90 \%(12,13)$. In a study conducted by Warren et al with malignant jaundice, cholangitis was present in $4.9 \%(14)$, while in our study cholangitis was present in $14 \%$ of patients at presentation. In present study the mean value of total bilirubin was $14.23 \mathrm{mg} / \mathrm{dl}$ and higher bilirubin levels were found in duodenal malignancy. In our study the mean value of ALP was 1061.84. Steer ML et al studied the laboratory values of carcinoma pancreas and reported that the mean values of total bilirubin were $8-9 \mathrm{mg} / \mathrm{dl}$, alkaline phosphatase 269.1IU/L (15). ERCP provides palliative treatment of malignant obstructive jaundice by CBD stent placement (16). In our study, CBD cannulation was achieved in 98.8\% cases, among which precut sphincterotomy was performed for $33 \%$ patients, one patient could not be cannulated(1.2\%).Among 29 patients who had precut sphincterotomy, 9 patients couldnt be cannulated initially, they were recannulated after 48 hours. Among the one patient who couldn't be cannulated had Carcinoma head of pancreas, he had underwent PTBD (Percutaneous Transhepatic Biliary Drainage) insertion eventually. The results of our study were comparable to the study done by Van der Gaag et al where initial stenting of common bile duct (CBD) was done in $\sim 75-100 \%$ of all patients with malignant obstructive jaundice (17). According to Sultan HM et al, successful stenting was achieved in 15 (75\%) of 20 patients. A study from the Netherland in 2010 illustrated that initial successful stent placement ranged from 69 to $83 \%$ in different hospitals (17). An Italian study showed successful endoscopic biliary decompression up to $86 \%$ (18). A study from Macedonia in 2012 showed the rate of initial successful stent placement of $70 \%$ for malignant pancreatic head neoplasm (19). Moreover, a study from Indonesia in 2012 showed successful endoscopic 
biliary decompression in $30.3 \%$ in malignant obstructive jaundice (20) According to Emre Balik et al, cannulation failure rate increased by 78 -fold in patients where periampullary tumors infiltrated or distorted the ampulla of Vater compared to patients with no such pathology. Plastic stent in our study was used for 73 patients, SEMS (self-expandable metallic stent) was used for 13 patients. Stent exchange rate was low $(4.7 \%)$ for the patients in the current study. 4 patients were readmitted for stent block and stent exchange. Among the four patients who had stent exchange at 3 months, 2 patients had carcinoma head of the pancreas and two patients had Ampullary growth, no cases of metallic stent had block at 3 months. The stent exchange rate was less in our study compared with previous study where approximately half of patients with malignant biliary obstruction treated with plastic stents required a stent change at 3 months. $(21,22)$. $55 \%$ of patients who underwent ampullary biopsy revealed malignancy. According to previous studies the ampullary biopsy sensitivity for periampullary tumours varied from from 21 to 81\% (23-26). Biliary brush cytology report revealed malignancy in 10 patients (35.7\%). According to Yamaguchi et al $35.7 \%$ of patients who underwent biliary brush cytology revealed malignancy. The results were comparable to other studies where the diagnostic accuracy for biliary brush cytology revealing malignancy has been reported to be from 45 to $85 \%$ (27-32). Limitation of our study was Endoscopic ultrasound has not been performed in above cases due to non-availability and referral biases of the cases to our hospital for ERCP.

\section{CONCLUSION}

In our study, ampullary growth was most common type of Periampullary tumour. Cholangitis was present in $14 \%$ cases at presentation. Successful ERCP and biliary drainage can be performed in majority of the patients. Ampullary growth biopsy and biliary brush cytology report sensitivity rate was $55 \%$ and $35.7 \%$ respectively. 3 months PC stent block was $4.6 \%$.

\section{Conflict of Interest}

No conflict of interest/no disclaimers.

\section{REFERENCES}

1. Jagannath $P$, Shrikhande $S$. Current options in the diagnosis and management of periampullary carcinoma. Indian J Surg. 2003; 65:347-53.

2. Benhamiche AM, Jouve JL, Manfredi S, Prost P, Isambert N, Faivre J. Cancer of the ampulla of Vater: results of a 20 -year population-based study. Eur $\mathrm{J}$ Gastroenterol Hepatol 2000; 12:75-9
3. Qiao QL, Zhao YG, Ye ML, Yang YM, Zhao JX, Huang YT. Carcinoma of the ampulla of Vater: factors influencing long-term survival of 127 patients with resection. W J Surg 2007; 31:137-43

4. Berberat PO, Kunzli BM, Gubinas A, Ramanauskas T, Kleeff J, Muller MW et al. An audit of outcomes of a series of periampullary carcinomas. Eur J Surg Oncol 2009; 35: 187-91

5. Sultan HM, Rageh TM, Khodeer HA. Factors affecting success rate of endoscopic retrograde cholangiopancreatography in malignant obstructive jaundice. Menoufia Med J (serial online) 2018 (cited 2019 Sep 11); 31:1165-8

6. Albores-Saavedra J, Schwartz AM, Batich K, Henson DE. Cancers of the ampulla of vater: demographics, morphology, and survival based on 5,625 cases from the SEER program. J Surg Oncol 2009; 100: 598-605

7. Talamini MA, Moesinger RC, Pitt HA, Sohn TA, Hruban RH, Lillemoe KD, Yeo $\mathrm{CJ}$, Cameron JL. Adenocarcinoma of the ampulla of Vater. A 28-year experience. Ann Surg 1997; 225: 590-599; discussion 599-600.

8. Nakase A, Matsumoto Y, Uchida K, Honjo I. Surgical treatment of cancer of the pancreas and the periampullary region: cumulative results in 57 institutions in Japan. Ann Surg 1977; 185: 52-57.

9. Bakkevold KE, Arnesjø B, Kambestad B. Carcinoma of the pancreas and papilla of Vater--assessment of resectability and factors influencing resectability in stage I carcinomas. A prospective multicentre trial in 472 patients. Eur J Surg Oncol 1992; 18: 494-507.

10. Walsh DB, Eckhauser FE, Cronenwett JL, Turcotte JG, Lindenauer SM. Adenocarcinoma of the ampulla of Vater. Diagnosis and treatment. Ann Surg 1982; 195: 152-157.

11. Neoptolemos JP, Talbot IC, Carr-Locke DL, Shaw DE, Cockleburgh R, Hall AW, Fossard DP. Treatment and outcome in 52 consecutive cases of ampullary carcinoma. Br J Surg 1987; 74: 957-961.

12. Brooks DC, Ostreen RT, Gray EB, Steele GD, Wilson RE. Evaluation of palliative procedures for pancreatic cancer. Am J Surg. 1981; 141:430-3.

13. Van Wagensveld BA, VanGulik TM, Obertop RH, GoumaDJ. Outcome of palliative biliary and gastric bypass surgery for pancreatic head carcinoma in 126 patients. Br J Surg. 1997;84:1402-6.

14. Warren KW, Christophi IC, Armedariz R, Basu S. Current trends in the diagnosis and treatment of carcinoma of the pancreas Am Surg. 1983;145:813-8.

15. Steer ML. Chronic biliary obstruction; hemodynamic effects of decompression. Surg Fourm. 1968:19;342-4.

16. Stern N, Sturgess R. Endoscopic therapy in the management of malignant biliary obstruction. Eur J Surg Oncol 2008; 34:313-317.

17. Van der Gaag NA, Rauws EA, van Eijck CH, Bruno MJ, van der Harst E, Kubben FJ, et al. Preoperative biliary drainage for cancer of the head of the pancreas. N Engl J Med 2010; 362:129-137.

18. Geraci G, Sciumè C, Pisello F, Li Volsi F, Facella T, Modica G, et al. Endoscopic palliation of obstructive jaundice caused by inoperable pancreatic cancer. Ann Ital Chir 2005: 76:473-476.

19. Deriban G, Andreevski B, Mishevski J, Krstevski M, Trajkovska M, Popova R, et al. Obstructive jaundice caused by pancreatic head malignancy are there predictive factors for successful endoscopic biliary stenting? Univ Gastroenterohepatol Clinic 2012; 33:59-71.

20. Oto BT, Fauzi A, Syam AF, Simadibra M, Abdullah M, Makmun D, et al. Identification and stenting of malignant obstructive jaundice: determining the success rate of ERCP. Indonesia J Gastroenterol Hepatol Dig Endosc 2012; 13:19-22.

21. Prat $F$, Chapat 0 , Ducot $B$, et al. A randomized trial of endoscopic drainage methods for inoperable malignant strictures of the common bile duct. Gastrointest Endosc 1998;47(1):1-7.

22. Soderlund $\mathrm{C}$, Linder $\mathrm{S}$. Covered metal versus plastic stents for malignant common bile duct stenosis: a prospective, randomized, controlled trial. Gastrointest Endosc 2006;63(7):986-95

23. Kimchi NA, Mindrul V, Broide E, Scapa E. The contribution of endoscopy and biopsy to the diagnosis of periampullary tumors. Endoscopy. 1998;30: 538-543.

24. Yamaguchi K, Enjoji M, Kitamura K. Endoscopic biopsy has limited accuracy in diagnosis of ampullary tumors. Gastrointest Endosc. 1990;36:588-592.

25. Huibregtse K, Tytgat GN. Carcinoma of the ampulla of Vater: the endoscopic approach. Endoscopy. 1988;20 Suppl 1:223-226.

26. Bourgeois N, Dunham F, Verhest A, Cremer M. Endoscopic biopsies of the papilla of Vater at the time of endoscopic sphincterotomy: difficulties in interpretation. Gastrointest Endosc. 1984;30:163-166.

27. Ryan DP, Schapiro RH, Warshaw AL. Villous tumors of the duodenum. Ann Surg 1986;203:301-6.

28. Sivak MV Jr. Clinical and endoscopic aspects of tumors of the ampulla of Vater. Endoscopy 1988:20:211-7.

29. Huibregtse K, Tytgat GNJ. Carcinoma ofthe ampulla of Vater: the endoscopic approach. Endoscopy 1988;20:223-6.

30. Leese T, Neoptolemos J, West KP, Talbot IC, Carr-Locke DL. Tumours and pseudotumours of the region of the ampulla of Vater: an endoscopic, clinical, and pathological study. Gut 1986;27:1186-92.

31. Blackman E, Nash SV. Diagnosis of duodenal and ampullary epithelial neoplasms by endoscopic biopsy: a clinicopathologic and immunohistochemical study. Hum Pathol1985:16:901-10.

32. Schultz TB, Baardsen A. Tubulo-papillary tumour ofthe papilla of Vater. A case report. Acta Chir Scand 1981;147:38 